\title{
Disclosure of Financial Statements and Its Effect on Investor's Decision Making in Jordanian Commercial Banks
}

\author{
Isam Saleh $^{1} \&$ Nawaf Alghusain ${ }^{2}$ \\ ${ }^{1}$ Department of Accounting, College of Business, Al-Zaytoonah University of Jordan, Amman, Jordan \\ ${ }^{2}$ Department of Banking and Finance, College of Business, Al-Zaytoonah University of Jordan, Amman, Jordan \\ Correspondence: Isam Saleh, Department of Accounting, College of Business, Al-Zaytoonah University of \\ Jordan, Amman, Jordan. Tel: 962-797-780-607. E-mail: i.saleh@zuj.edu.jo
}

Received: November 18, 2017

Accepted: December 22, 2017 Online Published: December 30, 2017

doi:10.5539/ijef.v10n2p20

URL: https://doi.org/10.5539/ijef.v10n2p20

\begin{abstract}
This study aims to examine the effect of financial information on investors decision making in commercial banks in Jordan. A questionnaire was adopted to address attitudes of professionals such as managers, analysts and investors and to identify to which degree the financial information was used in taking investment decisions. The results revealed a weak positive relationship between investment decisions and financial information that were provided by commercial banks in Jordan to the investors. This study recommended that adequate care and due diligence should be maintained in preparation of financial statements to avoid faulty investment decisions.
\end{abstract}

Keywords: investors, decision making, financial information, commercial banks

\section{Introduction}

The banking sector in any country is considered a vital and an important one for its impact on the country's economy either through the different banking operations or through financial and economic indicators provided by the financial companies and banks' annual financial statements which are considered a main information resource for a big number of economic sectors including the investors (Vestine \& Kule, 2016). On the other hand, disclosure plays a major role in addressing the problem of Information Asymmetry between managers and investors thus it increases agency problem (Diamond,1985; Easley et al., 2010). Therefore, the importance of data of the banks and the companies' annual financial statements is attributed mainly to its reliability and validity, in addition to its clarity and availability in the proper time (Frolov, 2004). Accordingly, any error or manipulation in the data leads to nonofficial decisions that affect the investors' interest and their economic and financial projects. Therefore, it is very important for the monetary authority represented by Central Bank and other control departments and organizations to have a strict control that ensures that banks and the financial companies enclose their data appropriately (Barth et al., 2002).

Nagar (1999) and Michael (2013) state that disclosure in the financial statements has played a significant role in preparing and publishing data and so this principle has attracted the attention of the accounting professional organizations, control bodies and the international stock exchange authorities. The financial statements are important to take different investment decisions as they focus on presenting the necessary financial information about the accounting unit including the efficiency of the management in performing its work. The financial information highlights the financial position of any company in a specific date, and shows the extent of its efficiency in managing its money by revealing its financial operations, achievement and the change in its financial position from one accounting period to another (Ahmed et al., 2006).

Financial statements are important in the Jordanian commercial banks that would help the investors to taking their investment decisions as well as the Central Bank and it would help in highlighting the means of information disclosure that raised the confidence of the statements' information. Therefore, this study addresses a vital and important economic sector in Jordan which is commercial banks by providing feedback of the banks' annual reports' users of Jordanian banks and Central Bank of Jordan, as well as highlighting empirical evidence relating to the value of annual reports that will clearly be beneficial for those who prepare Jordanian banks' annual reports based on the required accounting standards.

Accordingly, this study seeks to answer the following questions: 
1) Does the investor in Amman Stock Exchange rely on the Jordanian commercial banks' annual financial statements in making his investment decisions?

2) To which degree do the Jordanian commercial banks' annual financial statements provide the necessary information to the investor in Amman Exchange to make his investment decisions properly?

3) Is there a relationship between items of financial tools and its degree of disclosure in the Jordanian commercial banks' annual statements?

\section{Literature Review}

Financial statement can be described as financial information with reference to the economics activities of commercial banks. In addition, the function of financial statement is to assist investors in decision making regarding day-to-day operations and long-term plan of the bank (Mercy, 2014). According to Muinde (2013) financial statement is a standard practice of any organization to be prepared in a clear form for stakeholders in agreement with the board authority that regulates accounting information. In addition, Easley (2010) and Grüning (2011) state that the information included within the financial reports must be well-prepared and consist of high level of disclosure. This involves disclosure inside and outside the financial statements whether they were financial or non-financial information. Thus, it is worth to mention that the main goal of financial statements is to provide reliable information about the true and actual financial position of a business investment opportunity that could be useful to investors in making investment decisions.

Chong and Lai (2011) find that whenever investors tend to make their investment decision they are more likely to seek information about firm's ability to pay dividend as well as the behavior of other investors. Mercy (2014) states that the objective of information is emphasized by the various accounting principles because investors and creditors use them in their rational investment and credit decisions. In Taiwan, Shun and Chyan (2011) argue that due to lack of information and understanding of various risks, investors seek advice from financial experts. The financial analyst becomes useful in gathering, analyzing, and interpreting the accounting results for the sake of potential investors to be used in making investment decisions. Furthermore, investment bankers rely heavily on financial statement when they determine the sustainability of corporate businesses. Therefore, the financial statement helps bankers to create an appropriate price for transactions (Patrick et al., 2017).

Michael (2013) his research was conducted by means of a survey questionnaire of preparers of one hundred and fifty corporate investors and senior management officials of the selected banks. He found that the main responsibility of management to the investors is to give a standardized financial statement evaluated and authenticated by a qualified financial expert. In addition, the results indicated that investors depend heavily on the credibility financial expert approval of financial statement in making investment decisions and as such published financial statement is very important in the investors' decision making.

A study by Nasser et al. (2003) provided an exploration of the perceptions of various users of financial information in Kuwait. they found that annual report is the most important source of information, followed in this case by information obtained directly from the company and specialist advice. Abdulrazak (2013) found that investors used published financial statement to decide on the type of investment decision the investor will make and which company to invest in. as such financial statement of organizations should provide information about the economic resources of the organization, which is the source of prospective cash inflows to the company.

\section{Methodology}

\subsection{Research Hypothesis}

In this research, the following hypothesis are formulated:

H1: Disclosure in the annual financial statements of the Jordanian commercial banks helps the investor in Amman Exchange to make his investment decisions.

H2: There is a positive relationship between the reliance of the investor in Amman Stock on the information provided by the Jordanian commercial banks' annual statements and the success of his investment decision.

H3: There is no significant statistic relationship between the items of the financial tools and its degree of disclosure in the Jordanian commercial banks' annual financial statements.

\subsection{Data Collection}

Data were collected using a questionnaire which was developed by the researcher through reviewing the periodical, bulletins and studies related to the study's problem. The sample of the study consisted of the managers, analysts and investors in Amman stock Exchange representing 10 banks and 12 brokerage firms in 
Amman Stock Exchange. 180 questionnaires were distributed as follows: managers and investment decisions makers (50), financial analysts (50), and investors at Amman Stock Exchange (80). Only 138 questionnaires were retrieved as it is illustrated in the following table.

Table 1. Sample of the study

\begin{tabular}{lccc}
\hline Category & N distributed & Retrieved & Ratio of retrieved and analyzed questionnaires \\
\hline Financial analysts & 50 & 40 & $\% 75$ \\
Managers & 50 & 38 & $\% 76$ \\
Investors & 80 & 72 & $\% 86.7$ \\
Total & 180 & 150 & $\% 68.3$ \\
\hline
\end{tabular}

\subsection{Methods of Collecting Data}

Data were collected using a questionnaire includes:

- Clarification of the study's goals.

- A set of questions addressing the demographic description of the sample of the study (job title, years of experience, scientific qualification, rate of the investment decisions taken monthly and the department which is responsible of taking investment decisions.

- A set of questions aimed at identifying to which degree the information analysis was used in taking investment decisions. Having models of financial analysis is one of the means to identify the investors' needs of information since these models include indicators and ratios taken into account by the investor in the decision-making process. Additionally, these questions test the first hypothesis concerning the extent to which the investors rely on the information in the Jordanian commercial banks' annual financial statements in making his investment decisions.

Additionally, this study includes the financial statements published in 2015 by ten Jordanian commercial banks: Jordan Commercial Bank, Arab Bank, Cairo-Amman Bank, Jordan Kuwait Bank, Housing Bank, Bank of Jordan, Jordan Ahli Bank, Bank al Etihad, ABC Bank, Capital Bank.

Further, in the analysis of questionnaire responses across user groups, t-test and ANOVA test were used to evaluate the significance of differences in the sample means. The tests were conducted throughout using a conventional 5\% confidence level.

\subsection{Limitation of the Study}

The researcher faced many difficulties during the preparation of this study as weak of cooperation in filling the questionnaire especially the managers category and the difficulty in sending questionnaires to some mangers in the banks and the companies, in addition to the rejection of filling the questionnaires by other members of the study.

\section{Data Analysis and Results' Discussion}

Table 2 shows description of the sample.

Table 2. Description of the sample of the study

\begin{tabular}{llccc}
\hline $\mathbf{N}$ & Demographic description of the sample & \multicolumn{3}{c}{ Mean } \\
\cline { 3 - 5 } & & Financial Analysts & Decision Makers & Investors \\
\cline { 2 - 5 } $\mathbf{1}$ & Job title & 1.59 & 1.40 & 5 \\
$\mathbf{2}$ & Years of experience & 2.49 & 3.85 & 3.92 \\
$\mathbf{3}$ & Scientific qualification & 2.88 & 2.29 & 1.93 \\
$\mathbf{4}$ & Rate of decisions in month & 1.76 & 2.61 & 4.95 \\
$\mathbf{5}$ & Average of investment decisions success in a month & 3.60 & 3.54 & 3.57 \\
$\mathbf{6}$ & The responsible department for making investment decisions & 1.50 & 1.58 & 1.89 \\
\hline
\end{tabular}

The mean of the analysts category concerning job title variable was (1.59) which indicates that most of the members of this category were investment managers while the mean of investment decision makers was (1.40) indicating that most of the members of this category were financial managers. Additionally, the mean of investors category was (5). 
The mean of the analysts' category concerning the years of experience variable was (2.49) which indicates that most of the members' experience in this category ranged from 10 to 15 years whereas, the mean of the investment decisions makers' category was (3.85) with an experience ranged from 15 to 20 and the mean of investors category was 3.92 with experience ranged from 15 to 20 years.

The mean of the analyst's category concerning the scientific qualification variable was 2.88 which indicates that most of the members in this category were Master/high diploma degrees holders while the means of the decisions makers and investors categories were 2.29 and 1.93 respectively which means that the scientific qualification of these categories was bachelor and below.

The mean of the analysts group concerning the average of the number of the investment decisions taken during a month was (1.76) which indicates that the number of the decisions ranged from 11 to 20 while the mean of the investment decisions makers group was (2.61) revealing that the number of the decisions taken ranged from 21 to 40 . The investors' group mean was (4.95) and so more than 40 decisions were taken in a month.

The mean of the success of the investment decisions in the financial analysts and investment decision makers groups was (3.60) which indicates that the ratio of success was more than $75 \%$, whereas the mean of the investors group was (3.75) which means that $50 \%$ to $75 \%$ of the decisions taken in a month achieved their goals.

Concerning the responsible department of making investment decisions, the mean of the financial analysts group was (1.50) which means that the investment department is the one which is responsible while the mean of the decision makers group was (1.58) indicates that the board of directors / general director is the responsible for taking these decisions and so was the situation with investors group.

Based on the previous analysis, it can be concluded that there is a similarity to some extent between the investment decisions makers group and the investors group in terms of years of experience, scientific qualification, and the responsible department of making decisions.

The first question in the second part of the questionnaire addressed the process and procedures followed in making investment decisions to identify the extent to which the information analysis is reliable in the process of investment decisions making. Results are illustrated in Table 3.

Table 3. Process of making the investment decision by the financial analysts, investment decision makers and investors

\begin{tabular}{|c|c|c|c|c|c|c|c|}
\hline \multirow[t]{2}{*}{$\mathbf{N}$} & \multirow[t]{2}{*}{ Process of decision making } & \multicolumn{2}{|c|}{ Financial analysts } & \multicolumn{2}{|c|}{ decision makers } & \multicolumn{2}{|c|}{ Investors } \\
\hline & & $\mathbf{N}$ & $\%$ & $\mathbf{N}$ & $\%$ & $\mathbf{N}$ & $\%$ \\
\hline 1 & Constant information analysis according to specific models & 18 & $24.9 \%$ & 12 & 24.2 & 0 & 0 \\
\hline 2 & information analysis(sometimes) according to specific models & 38 & $57.1 \%$ & 32 & $75.8 \%$ & 8 & $12.5 \%$ \\
\hline 3 & information analysis according to non- specific models & 0 & 0 & 0 & 0 & 32 & $55.6 \%$ \\
\hline 4 & No information analysis & 0 & 0 & 0 & 0 & 24 & $31.9 \%$ \\
\hline \multicolumn{2}{|c|}{ Total } & 56 & $100 \%$ & 44 & $100 \%$ & 64 & $100 \%$ \\
\hline
\end{tabular}

Table 3 shows that most members of the financial analysts group made their investment decisions through relying, sometimes, on information analysis according to specific models with (75.1\%). Similarly, the investment decision makers group made sometimes their investment decisions according to specific models with (75.8). Accordingly, the models used by these two groups could be considered one of the ways to identify their needs. While the members of the investors in Amman Stock Exchange group made their investment decisions based on information analysis without using any specific models with (55.6\%) and the rest of this group made their decisions without analyzing the information and this may due to their continuous knowledge of the stock exchange as well as the number of the decisions that they need to make within specific periods of time.

Testing first hypothesis: "Disclosure in Jordanian commercial banks'financial statements help the investors in Amman stock exchange to make his investment decision".

This hypothesis was tested by analyzing the sample's responses for the second part of the questionnaire concerning the first hypothesis which included the relative significance of the sources of information adopted by the investor in making his investment decisions. Results were shown in table 4. 
Table 4. Relative significance of the sources of information adopted by the financial analysts, investment decision makers and investors in Amman stock exchange during the process of investment decision making

\begin{tabular}{|c|c|c|c|c|c|c|c|c|}
\hline \multirow[b]{2}{*}{$\mathrm{N}$} & \multirow[t]{2}{*}{ Source of information } & \multicolumn{2}{|c|}{ Financial analysts } & \multicolumn{2}{|c|}{ decision makers } & \multicolumn{2}{|c|}{ Inventors in stock exchange } & \multirow[t]{2}{*}{ Sig. } \\
\hline & & $\mathrm{M}$ & STD & $\mathrm{M}$ & STD & M & STD & \\
\hline 1 & Information presented by Amman stock exchange & 4.85 & 0.35 & 4.58 & 0.59 & 3.87 & 0.74 & 0.248 \\
\hline 2 & Annual financial statements & 4.79 & 0.31 & 4.68 & 0.46 & 4.61 & 0.50 & 0.181 \\
\hline 3 & Quarterly financial statements & 4.55 & 0.69 & 3.99 & 0.66 & 3.84 & 0.71 & 0.289 \\
\hline 4 & Direct contact with the company's management & 3.10 & 0.73 & 3.18 & 0.87 & 3.11 & 0.78 & 0.320 \\
\hline 5 & The company's news published in the newspapers & 3.34 & 0.60 & 2.65 & 0.97 & 3.38 & 0.90 & 0.277 \\
\hline
\end{tabular}

The results in Table 4 showed that the annual financial statements are one of the most important reliable and dependable resources of information for taking investment decisions from the perspective of the three groups with means (4.79), (4.69) and (4.61) respectively. This result proved the significance of the annual statements is one of the resources of information that helps in making investment decisions. The item got low standard deviation (0.31), (0.46) and (0.5) respectively which indicated a match in the respondents' perspective towards the importance of this item.

Additionally, ANOVA results revealed that the significance degree among the three groups was $(0.181)$ that assured lack of significance among the three groups in their reliance on the annual financial statements as a source of information and so the first hypothesis was accepted.

The second part of the questionnaire raised a question with two parts about the information ratio provided by the financial statements to the investor in Amman stock exchange to help him make investment decisions and the reasons that restrict the adoption of these statements.

a) Table 5 shows information ratio provided by the financial statements to the investor in Amman stock exchange:

Table 5. Information ratio provided by the financial statements to the investor in Amman stock exchange

\begin{tabular}{lccc}
\hline formation ratio & Financial analysts & Investment decision makers & Investors \\
\hline Less than 25\% & 0 & $7 \%$ & $12 \%$ \\
$25 \%-50 \%$ & 0 & $14.2 \%$ & $66.1 \%$ \\
$50 \%-75 \%$ & $18 \%$ & $27 \%$ & $2 \%$ \\
More than 75\% & $73 \%$ & $51 \%$ & 0 \\
not rely on annual report & $9 \%$ & 0 & $21.1 \%$ \\
\hline
\end{tabular}

It is clear from the previous table, the information ratio provided by the Jordanian commercial banks' annual financial statements to the financial analysts and investment decisions makers groups was more than $75 \%$ of the required information, whereas the ratio for investors group ranged from $25 \%$ to $50 \%$.

b) Regarding the non-reliance on the annual financial statements in making investment decisions,six out of forty (analysts group) and sixteen out of eighty (investors group)answered that they did not rely on banks' annual financial statements in making their investment decisions while the investment decisions makers group did not answer this question. T test was used to identify the relative significance of the investor's lack of reliance on the Jordanian commercial banks' annual financial statements as it is illustrated in Table 6:

Table 6. Relative significance of the investor's lack of reliance on the Jordanian commercial banks' annual financial statements

\begin{tabular}{llrrrr}
\hline & Reasons of non-reliance on Jordanian commercial banks' annual financial & \multicolumn{2}{c}{$\mathrm{M}$} & Sig. & Notes \\
\cline { 2 - 5 } $\mathrm{N}$ & statements & Analysts & Investors & & \\
\hline 1 & The statements covered extended period & 5.0 & 5.0 & 0.808 & Non \\
2 & There are better information resources in meeting the investors' needs & 5.0 & 5.0 & 0.808 & Non \\
3 & Information are not trusted & 4.0 & 4.0 & 0.808 & Non \\
4 & The auditors' report about that banks' statements is not objective and does not & 5.0 & 5.0 & 0.808 & Non \\
& reflect real situation & & & \\
5 & Not published in the appropriate time & 6.0 & 6.0 & 0.725 & Non \\
\hline
\end{tabular}


There is a total agreement in the analysts and investors groups' responses in identifying reasons for not adopting the Jordanian commercial banks' annual financial statements in their investment decisions. Moreover, the table showed lack of significant difference between the two groups.

Testing second hypothesis: "There is a positive correlation between the investor's reliance on the information provided by the Jordanian commercial banks". This hypothesis was examined using the Pearson Correlation Coefficient and the results are illustrated in Table 7:

This table showed a positive correlation between the average of the information provided by the Jordanian commercial banks financial statements to the investors in Amman stock exchange and between the average of the successful decisions taken in a month. The Pearson correlation for the investment decisions makers' group was (0.442), followed respectively by the financial analysts group (0.424) and investors in Amman Stock exchange (0.081).

Table 7. Results of the relationship between information ratio provided by the Jordanian commercial banks' annual financial statements to the investor in Amman stock exchange and between the average of the investment decisions success ratio taken in a month

\begin{tabular}{lllll}
\hline Group & $\begin{array}{l}\text { Average of information ratio } \\
\text { provided by the financial statements }\end{array}$ & $\begin{array}{l}\text { Average of investment decisions } \\
\text { success ratio in a month }\end{array}$ & $\begin{array}{l}\text { Correlation } \\
\text { coefficient }\end{array}$ & P \\
\hline Financial analysts & 3.12 & 3.16 & 0.424 & 0.522 \\
Decision makers & 3.68 & 3.16 & 0.442 & 0.566 \\
Investors & 2.02 & 6.23 & 0.081 & 0.699 \\
Whole sample & 2.59 & 3.19 & 0.241 & 0.049 \\
\hline
\end{tabular}

Table 8. Items in the third part of the questionnaire which their means ranged between (3.5-5)

\begin{tabular}{|c|c|c|c|}
\hline $\mathrm{N}$ & Item & M & Sig \\
\hline 13 & Interests received and similar revenues & 3.57 & Sig \\
\hline 14 & Paid interests and similar revenues & 3.56 & Sig. \\
\hline 15 & Profits and losses arising from trading with bonds & 4.66 & Sig. \\
\hline 16 & Profit after deducting losses resulted from bonds investment & 4.61 & Sig. \\
\hline 1 & asset and liability groups according to their nature & 3.54 & Sig. \\
\hline 2 & Assets order according to its relevant liquidity & 4.19 & Sig. \\
\hline 8 & Treasure bonds or any other discountable bonds in Central Bank & 4.08 & Sig. \\
\hline 7 & Governorate bonds and others held for trading & 4.70 & Sig. \\
\hline 6 & Deposits in other banks and facilities given to them & 4.42 & Sig. \\
\hline 5 & Deposits in other financial markets & 4.01 & Sig. \\
\hline 21 & $\begin{array}{l}\text { Investment and trading bonds activate trading in the market (especially if market value differs from the book } \\
\text { value) }\end{array}$ & 4.54 & Sig. \\
\hline 20 & Investing in shares in stock exchange if the banks keep them for trading & 4.60 & Sig. \\
\hline
\end{tabular}

Regarding to Table 7, there was a weak positive correlation as Pearson correlation was (0.241). Moreover, $\mathrm{P}$ value was $(0.05)$ which indicates lack of significant differences between the members of the study's sample and therefore, the second hypothesis was accepted.

Testing the third hypothesis: "There is an important statistical relation between the item's importance and its degree of disclosure in the Jordanian commercial banks' annual financial statements".

This hypothesis was tested through identifying disclosure ratio for each item as it was explained previously. The items which its means ranged from 3.5 to 5 were 16 out of 37 as it is illustrated in table (8).

Table 9 showed that all Jordanian commercial banks (the sample of the study) exceeded the ratio of disclosure in their financial statements in 2015 with 50\%. In addition, Arab Bank got the highest ratio in terms of disclosure in its financial statements with (75.1\%) followed by the Cairo-Amman Bank with $(69.3 \%)$ whereas ABC Bank and the Capital banks were the least in disclosure with (52.3\% and 52.2\%) respectively. 
Table 9. Banks' disclosure ratio

\begin{tabular}{lll}
\hline $\mathrm{N}$ & Commercial Banks & Disclosure ratio \\
\hline 1 & Arab Bank & $\% 75.1$ \\
2 & Amman-Cairo Bank & $\% 69.3$ \\
3 & Jordan Kuwait Bank & $\% 65.6$ \\
4 & Housing Bank & $\% 63.2$ \\
5 & Jordan Bank & $\% 61.8$ \\
6 & Jordan Ahli Bank & $\% 60.3$ \\
7 & Jordan Commercial Bank & $\% 57.6$ \\
8 & Bank al Etihad & $\% 54.6$ \\
9 & ABC Bank & $\% 52.3$ \\
10 & Capital Bank & $\% 52.2$ \\
\hline
\end{tabular}

In light of the previous results, it is clear that the Jordanian commercial banks' annual financial statements provide (61.21) of the necessary information that help in taking the investment decisions. And therefore, there is a significant statistical relation between the item's importance and its degree of disclosure in these reports. Accordingly, the third hypothesis was accepted.

\section{Discussion and Recommendations}

Results of this study showed that the perspective of the financial analysts and investment decisions makers groups matched as the two groups believe that the investment decisions are based mainly on information analysis according to specific models. At the same time, most of the members of the investors group believed that their investment decisions were not based on any specific models although the adoption of specific models made it easier for the users of these models to identify their needs of the information but there are some decisions with low degree of significance taken daily without adopting any specific models. In addition, the Jordanian commercial banks' annual statements were considered one of the most important resources of information which the investors rely on with a mean (4.79) in the group of financial analysts and (4.61) in the investment decisions makers' group. These statements which affect the investors' investment decisions can be developed in terms of content to suit the needs of the users of these statements.

The relevant significance of other information resources (information published by Amman stock exchange, the direct contact with the company's management and the company's published information in the newspapers) between the financial analysts and investment decision makers groups was homogeneous but this significance varied according to the quarterly financial statements. The three groups agreed that the information published by Amman stock exchange came in the second rank in terms of its significance as a source of information which means that the three groups relied on other information resources to make their investment decisions and so having sufficient disclosure in the Jordanian commercial banks' annual financial statements which meets the needs of all categories of investors in Amman Stock Exchange in the appropriate time will facilitate the process of taking investment decisions by the adoption of one main resource of information rather than looking for other resources.

Results also showed that the companies' published news in the newspaper was the least significant resource of information which indicates that the news published in the newspaper do not meet the investors' needs of information. On the other hand, the three groups agreed that there was a positive correlation between the average of information provided by the Jordanian commercial banks' annual financial statements to the investors in Amman stock exchange and the average of the success of the investment decisions as Pearson correlation coefficient was $(0.251)$ for the whole sample. Further, the mean of the disclosure in the Jordanian commercial banks' annual financial statements was (61.21) and this enhanced the investors' trust of these statements as a source of information.

The results of this study proposed the following: First, the necessity to issue the annual financial statements with their details and without any deletions. Second, the interested institutions as the profession council and auditors organization need to adopt the international accounting standards' requirements to fit the Jordanian legislations and laws. Third, the coordination between the Central Bank of Jordan, Jordan Securities Commission, the banks association and any other concerned entity in establishing an independent website includes all the information which investors care about whether it was inside or outside Jordan. Fourth, departments in the Jordanian universities make a contact with public institutions, banks and the companies to cooperate with the scholars and provide them with information and data that help them in their researches. 


\section{References}

Abdulrazak, M. (2013). The Effect of Adopting International Financial Reporting Standards on Quality of Accounting Reports of Small and Medium Enterprises in Nairobi County. International Journal of Business and Management, 2(4), 17-25. Retrieved from http://erepository.uonbi.ac.ke:8080/xmlui/handle/123456789/58735

Ahmed, A. S., Kilic, E., \& Lobo, G. (2006). Does Recognition versus Disclosure Matter? Evidence from Value-Relevance of Banks' Recognized and Disclosed Derivative Financial Instruments. The Accounting Review, 81, 567-588. https://doi.org/10.2308/accr.2006.81.3.567

Barth, J. R., Dopico, L. G., Nolle, D. E., \& Wilcox, J. A. (2002). Bank safety and soundness and the structure of bank supervision: A cross country analysis. International Review of Finance, 3, 163-188. https://doi.org/10.1111/j.1369-412X.2002.00037.x

Chong, T. P., \& Lal, M. M. (2011). An empirical evidence of factors in equity selection process in Malaysia. African Journal of Business Management, 5(15), 6221-6232.

Diamond, D. W. (1985). Optimal Release of Information by Firms. Journal of Finance, 40(4), 1071-1094. https://doi.org/10.1111/j.1540-6261.1985.tb02364.x

Easley, D. (2010). Financial statement and investment decision. International Journal of Business and Commerce, 3(8), 58-69.

Easley, D., Hrickjaer, S., \& O'Hara, M. (2010). Factoring information into returns. Journal of Finance, 45, 293-309. https://doi.org/10.1017/S0022109010000074

Frolov, M. (2004). Why Do We Need Mandated Rules of Public Disclosure for Banks? Kumarp Discussion Paper Series, DP2004-010, Keio University, Japan. https://doi.org/10.1057/palgrave.jbr.2350045

Grüning, M. (2011). Capital Market Implications of Corporate Disclosure: German Evidence. Business Research, 4(1), 48-72. https://doi.org/10.1007/BF03342726

Mercy, A. A. (2014). The role of financial statement in investment decision making; A case study of first bank of Nigerian Plc). International Journal of Accounting Information System, 2, 91-105.

Michael C. E. (2013). Reliance on Published Financial Statements and Investment Decision Making in the Nigeria Banking Sector, European Journal of Accounting Auditing and Finance Research, 1(4), 67-82.

Muinde, C. (2013). Relationship Between Financial Reporting and Analysis Practices and Financial Performance of Small and Medium Enterprises in Kenya. International Journal for Management Science and Technology, 2(3), 30-35. http://erepository.uonbi.ac.ke:8080/xmlui/handle/123456789/59856

Nagar, V. (1999). The Role of Managers' Human Capital in Discretionary Disclosure. Journal of Accounting Research Supplement, 37, 167-181. https://doi.org/10.2307/2491351

Naser, N., Nuseibeh, R., \& Al-Hussaini, A. (2003). Users' perceptions of various aspects of Kuwaiti corporate reporting. Managerial Auditing Journal, 18(6/7), 599-617. https://doi.org/10.1108/02686900310482731

Patrick, Z., Tavershima, A., \& Eje, B. E. (2017). Effect of Financial Information on Investment Decision Making by Shareholders of Banks in Nigeria. Journal of Economics and Finance, 8(3), 20-31. https://doi.org/10.9790/5933-0803032031

Shun, R., \& Chyan, T. (2011). Factors influencing individual investor behavior. International Journal of Business and Management, 16(2), 68-76.

Vestine, M., \& Kule, J. W. (2016). Effect of Financial Statement Analysis on Investment Decision Making. A Case of Bank of Kigali. European Journal of Business and Social Sciences, 5, 279-303. Retrieved from http://www.ejbss.com/recent.aspx-/

\section{Copyrights}

Copyright for this article is retained by the author(s), with first publication rights granted to the journal.

This is an open-access article distributed under the terms and conditions of the Creative Commons Attribution license (http://creativecommons.org/licenses/by/4.0/). 